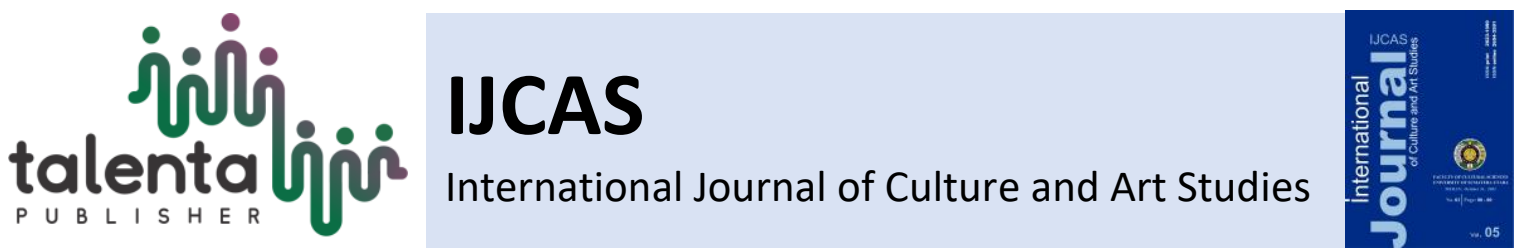

\title{
The Meaning of Nyangahatn Ritual of Dayak Kanayatn Community for Disaster Mitigation
}

\author{
Mohammad Maulana Magiman ${ }^{1}$, Ary Sulistyo ${ }^{2}$, Jeanne Francoise 3* $^{*}$ \\ ${ }^{1}$ Faculty of Social Sciences and Management, Universiti Putra Malaysia, Bintulu Campus Sarawak, \\ Malaysia. \\ ${ }^{2}$ Cultural Protection Directorate, Ministry of Education and Culture of Republic Indonesia, Jakarta, \\ Indonesia. \\ ${ }^{3}$ Department of International Relations, President University, Bekasi, Indonesia.
}

\begin{abstract}
This research focused on the Nyangahatn ritual in Dayak Kanayatn indigenous people in West Kalimantan. This study uses a descriptive qualitative research method with a phenomenological approach with an emphasis on literature study. This paper uses the cultural theory, human ecology, and Disaster Mitigation and shows that there is a connection between those theories in Nyangahatn people's rituals. Nyangahatn ritual related to the cultivation practices carried out based on the rice planting cycle. The results showed that the Nyangahatn ritual is a pearl of local wisdom, which is an effort in mitigating and adapting to disasters, especially regarding the planting and harvesting seasons. Forests or land cleared for cultivation are very calculated to avoid degradation and air sources. The Kanayatn Dayak indigenous people are very understanding about natural signs. In the process of land clearing for agriculture, it is essential to consider the land area is to be planted so that it does not disturb the forest ecosystem. Meanwhile, the culture of balale' or gotong royong as a form of solidarity and harmony between community members is still maintained.
\end{abstract}

Keywords: Dayak kanayatn, Disaster mitigation, Local wisdom, Nyangahatn ritual

Received 27 September 2021 | Revised 13 October 2021 | Accepted 31 October 2021

\section{Introduction}

Humans, through their culture, become a tool to interact with the physical and biotic environment. In the culture of any community, there are usually elements of local culture such as language, knowledge systems, social organization, living equipment systems and technology, livelihood systems, religious systems, and arts (Koentjaraningrat, 2002, pp. 203-204). Ecologically, humans are an integral part of their environment. Humans are formed by their environment, and vice versa; humans shape their environment. Therefore, human survival depends on the integrity of their environment (Soemarwoto, 2007, p. 25).

\footnotetext{
*Corresponding author at: Department of International Relations, President University, Kota Jababeka, Cikarang Baru, Bekasi 17550 - Indonesia

E-mail address: monicajeannefrancoise@gmail.com
} 
In the context of human and environmental relations, the community who are still dependent on natural resources assume that supernatural forces significantly affect life and culture or way of life, that everything sacred and numinous (Latin: evokes spiritual and religious emotions) is an adaptive human nature as biological beings and adaptive nature in the social process in which humans organize themselves (Rappaport, 1999, p. 414). Thus, religious and ritual conceptions are explorations of human internal logic but also prerequisite considerations for exploring human relations in society and nature (Ibid., pp. 407). Rituals can be described as special unplanned actions that are routine, habitual, obsessive, or mimetic - and therefore purely formal, secondary, and logically physical expressions before ideas (Bell, 2009, p. 19). So that the ritualization process, as an effective mode of strategic action in a certain social order, but not in the sense of controlling individuals or society (Bell, 2009, p. 170).

Therefore also applies to the Bidayuh community; it is a collective term for the community in several sub-tribes of the Dayak Darat in Sarawak, Malaysia, and Dayak sub-tribe spread across several districts in West Kalimantan. During the colonial period, this community was better known as "Land Dayak" or "Dayak Darat" to distinguish them from the Iban community who was commonly called "Sea Dayak" or "Dayak Laut." The term of Land Dayak is used to describe the location of their settlements, most of which are in the interior, upstream of rivers and highlanders. The settlement of the Bidayuh Dayak sub-tribe was originally located on the coast. However, after the arrival of groups of the Iban community who attacked their villages, killed and made them slaves, the survivors fled to the forest and built villages on hilltops, rivers upstream, and the edges of ravines that were very difficult for outsiders to reach. The area around their residence is fenced with many traps to protect it from being easily attacked by outsiders. Thus, it is common for many Dayak Bidayuh villages to be located in mountainous and highland areas (Purwana, 2019, p. 19). This ethnic group is the largest Dayak ethnic group in the state of Sarawak, after the Iban Dayak (Purwanto, 2009, p. 8).

In West Kalimantan, Indonesia, the Dayak Bidayuh sub-ethnic group is the third largest ethnic group after the Iban and Kanayatn. The settlement of the Dayak Bidayuh sub-ethnic group spread across the districts of Sanggau, Sekadau, Bengkayang and Ketapang. The largest population of the Dayak Bidayuh community in West Kalimantan is in the Bengakayang area. Based on existing oral tradition, the Dayak Bidayuh in Sarawak, Malaysia and Dayak Bidayuh in West Kalimantan, Indonesia are one family (Purwana, 2009, p. 67). 


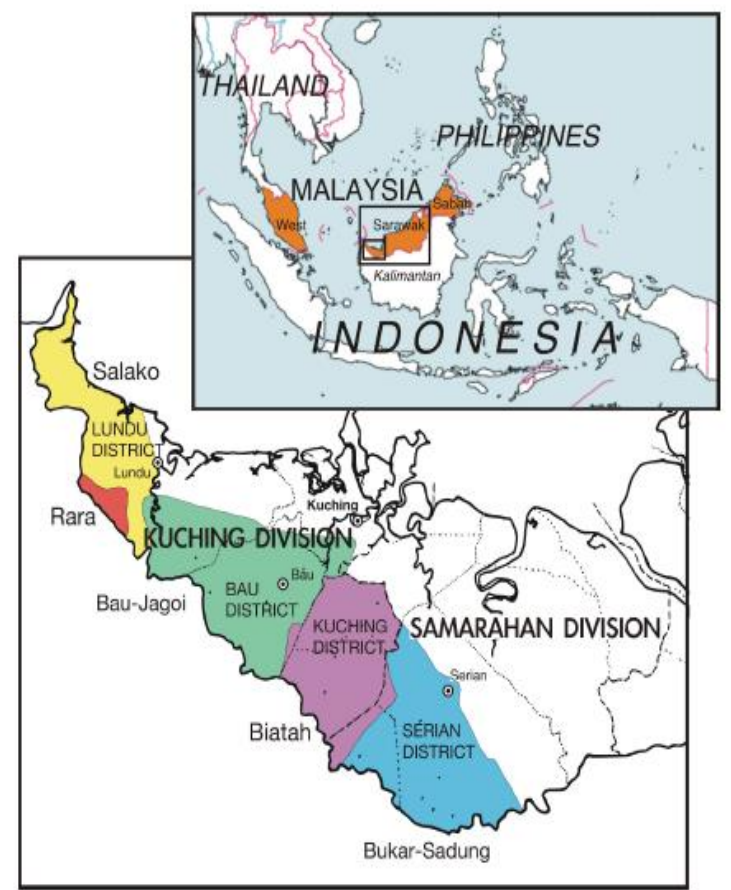

Figure 1. The dispersion of Dayak Bidayuh at the Border of Indonesia-Malaysia (Sarawak) (Source: Rensch, et al., 2012, p. 3)

Based on the research results conducted by the Ministry of Culture and Tourism (2009:18-21), that the ancestors of the Dayak Bidayuh tribe came from Sungkung, who inhabited Mount Sijakng Singulikng in the Kengkayang Regency area named Siang Nuk Nyinukng. The Descendants of Siang Nuk Nyinukng who spread or migrated to areas. One of the causes of the descendants of Siang Nuk Nyinukng out and spreading from Mount Sijikng Singulikng is their efforts to find fertile land that will be used for farming activities. Another factor is that they are often involved in civil wars because of land disputes and territorial disputes. This Civil war is often carried out by enriching the enemy's head.

Salako or Salakau is one of the Bidayuh sub-tribes living in Sarawak. In the past, the indigenous people of Salako were known locally as Salacus and were not categorized as Dayak Bidayuh. This is because ethnic groups have significant differences in dialect, culture, and dress. However, since the 1970s, the Salako sub-tribe has been assimilated with the Bidayuh indigenous people due to political similarities. The Salako population is decreasing, and most of them live in areas such as Sematan and Lundu, Sarawak. 


\section{$2 \quad$ Literature Review}

\subsection{Culture theory}

Culture as an adaptive system has an understanding as a system of socially inherited behavior patterns that work to connect human communities with their ecological environment. This "community way of life" includes technology and forms of economic organization, settled patterns, forms of social grouping and political organization, religious beliefs, and practices. (Keesing, 1974, p. 39).

The Dayak Bidayuh indigenous people lived on the border between Indonesia and Malaysia in West Kalimantan (particularly in Landak and Bengkayang districts). One of the well-known rituals still carried out by the indigenous Dayak Bidayuh, especially the Dayak Kanayant, is the Nyangahatn ritual. The Salako indigenous community in Sarawak, Malaysia are known as the Kanayatn Dayak in West Kalimantan. However, some consider it different, but from the perspective of language and religion, these two tribes have something in common (Magiman et al., 2020: 3008-3009).

The Dayak Kanayatn community holds the ritual of Nyangahatn, which is offered and invoked to Jubata (The Divine) led by a shaman who recites prayers orally, which sounds like a prayer of thanksgiving. Nyangahatn is often categorized as non-story oral literature. This ritual is carried out following the customary proverb nang diunak, dinali, dinamputn, which means the custom that has existed since human existence, the custom that is followed and continued from generation to generation. Nyangahatn is closely related to the religious behavior of the community and activities related to the original beliefs. An example is Nyangahatn in plantation practices implemented based on the rice planting cycle (Directorate of Heritage and Cultural Diplomacy, 2018, p. 336).

\subsection{Human ecology}

The word ecology comes from the Greek words oikos and logos. Oikos means house, and logos means knowledge. The first person introduced to developing the concept of ecology was a German philosopher and biologist, Ernest Haeckel, in 1869, who defined ecology as the study of the pattern of the relationship between organisms and their environment (Odum, 1983: 1). Humans are a group of individuals, an animal species population (Soerjani et al., 1987, p. 4).

As living beings that cannot live by themselves or social beings, humans are also part of a larger network of life (the web of life) and other types of living things. Several conceptual views in ecological anthropology regarding the concept of human-environment interaction can be used in this research. In essence, an adaptive system where culture changes towards a balanced 
ecosystem. However, if the balance is disturbed by changes in the environment, population, technology, or other systemic changes, the changes that occur as further adjustments will emerge through the cultural system (Keesing, 1974, p. 40).

\subsection{Disaster mitigation}

A disaster is an event or series of events that threaten and disrupt people's lives and livelihoods caused, either by natural factors and/or non-natural factors as well as human factors, resulting in human casualties. Natural disasters, non-natural disasters, and social disasters (Law of Republic Indonesia Number 24 of 2007 concerning Disaster Management). Data from the National Disaster Management Agency or Badan Nasional Penggangulangan Bencana (BNPB) Republic Indonesia in West Kalimantan during 2013-2015 noted that in Landak Regency, for example, it has four (4) potential disasters. The four disasters are landslides, floods, hurricanes, and fires, including forest fires and residential fires, with the dominance of flood disasters (Wahyuningtyas and Pratomo, 2015, p. 12).

The cultural landscape can be used as the basis for the preservation of natural resources, especially in preventing forest degradation and deforestation, which can lead to flooding. The conservation of existing natural resources is in the form of preserving biological resources and their conservation through custom (system values) and customary processes in communities that live through ritual traditions such as the Bidayuh Dayak indigenous community.

Linguistically local wisdom consists of two words local and wisdom. Local means home-grown, sectional, of the same place, while wisdom can be interpreted as wise thoughts, ideas, or behavior. In the context of local wisdom, every society, including traditional communities, basically, there is a process to become able and knowledgeable. This is related to the desire to be able to maintain and carry on life so that community spontaneously think about it, ways to do, make, and create something that is needed while processing natural resources in order to ensure the sustainability and availability of natural resources without disturbing the balance of nature.

Local wisdom in Indonesia can be categorized into two aspects: local wisdom is tangible and intangible. This discussion focused on intangible local wisdom, intangible local wisdom such as advice that is conveyed verbally and from generation to generation, which can be in the form of songs or kidung that contain traditional teaching values. Through advice or other intangible forms of local wisdom, social values are conveyed orally or verbally from generation to generation. In addition, some traditional beliefs and rituals are applied and believed by the community to prevent disasters and express gratitude to the Divine. One of the impacts of local wisdom is the psychological aspect or mindset of the people becoming more aware in their work, especially in 
dealing with disasters and protecting nature as a form of gratitude (Juhadi, Muis, and Sriyanto, 2018, p. 27-28).

\section{Method}

This research uses a descriptive qualitative research method with a phenomenological approach and an emphasis on literature study". The data collection step is carried out by collecting and selecting the results of research that has been carried out on the Kanayant indigenous community in West Kalimantan, whether carried out by institutions, in this case, the Ministry of Culture and Tourism of Indonesia (now the Ministry of Education, Culture, Research and Technology of Indonesia), research's both from various institutions and individuals that have been published both online and in print.

The data processing step is carried out in the form of an analysis of cultural theories in the context of culture as an adaptive system and its relationship to disaster communication, especially in local communities through rituals. In this case, local wisdom, especially rituals, has intangible values, both in human relations to God, with nature, and with others.

The next step is an interpretation based on the results of data collecting and analysis of the values of local wisdom, specifically the Nyangahatn traditional ritual for the Dayak Kanayant indigenous community in terms of disaster mitigation and the meaning of rituals, especially as identity concerning environmental conservation.

\section{$4 \quad$ Findings and Discussions}

In general, the indigenous Dayak Kanayant communities are peasants and cultivators. Some of them are settled cultivators, where cultivated land is done every year, and shifting cultivators are only done during dry seasons. A slash and burn cultivation system is a cultivation system that is done when cultivators conducted that the fertility level of the land is sufficient by cutting, burning, and planting. Cultivation areas are cultivated for 4 or 5 years in a row, then abandoned after the fertility level becomes low; in less than the next ten years, the abandoned area will be reopened (Berianto, 2013, p. 34).

The Nyangahatn ritual for the Kanayatn Dayak cultivating community has an important meaning in the life cycle, such as birth, marriage and death, farming activities, and medication. The Nyangahatn ritual involves the community lead or Kepala Desa as the person chosen by the

\footnotetext{
* Due to COVID-19 pandemic, the researchers are not be able to conducting field study from the period 2020-2021
} 
residents and has an important role in social life. Then Panyangahatn (spellcaster) plays the role of leading and chanting prayers or incantations in rituals. Then there is Panyanakng Kalangkakng (companion of Panyanghatn), who is conducted helping complete the ritual offerings. Finally, the family and community participate in the ritual for the ritual of gratitude or the ritual of healing the disease.

Nyangahatn ritual equipment's in the form of offerings consisting of trees (usually as an altar to God), lime paste (kapur sirih), water from the river, manok (chicken), tumpi' ( $\underline{\text { cucur }}$ or traditional cake made from rice flour), poe' (pulut or lemang or rice roasted in bamboo tubes), bontokng (rice wrapped in leaf cooked in spices), talo' (eggs), gulita (pelita or oil lamp), kobet (offerings placed on leaves with chicken blood, cucur, pulut, lontong or rice cake, salt, and eggs), money, rice, baras sasah (rice mixed with water), langir or merbuan (Albizia Saponaria) bark, oil, flowers, tungkat (pulut cooked in long bamboo and with a hole in the middle).

At the preparatory stage, the Nyangahatn ritual is usually carried out at each cycle of rice cultivation, either at the time of planting or post-harvesting (annually). This ritual is performed as a form of gratitude to Jubuta (the Divine) for the harvest's success or the failure of the harvest. The Nyangahatn ritual will usually be closed with another more simple that is the Naik Dango ritual. The ritual implementation will be led by a unique traditional officer who handles rice by Tuha Tahutn. The ritual can be done near the rice fields or at home. In principle, the implementation of the Nyangahatn ritual either by means of Nyangahatn Manta' (without the sacrificial animal or the sacrificial animal has not been slaughtered) or Nyangahatn Masak' (the sacrificial animal has been slaughtered) is the same. The implementation process of both is filled with three activities, namely Matik (intent prayer), Ngalantekatn (salvation prayer), and Mibis (prayer for all to reach their goal).

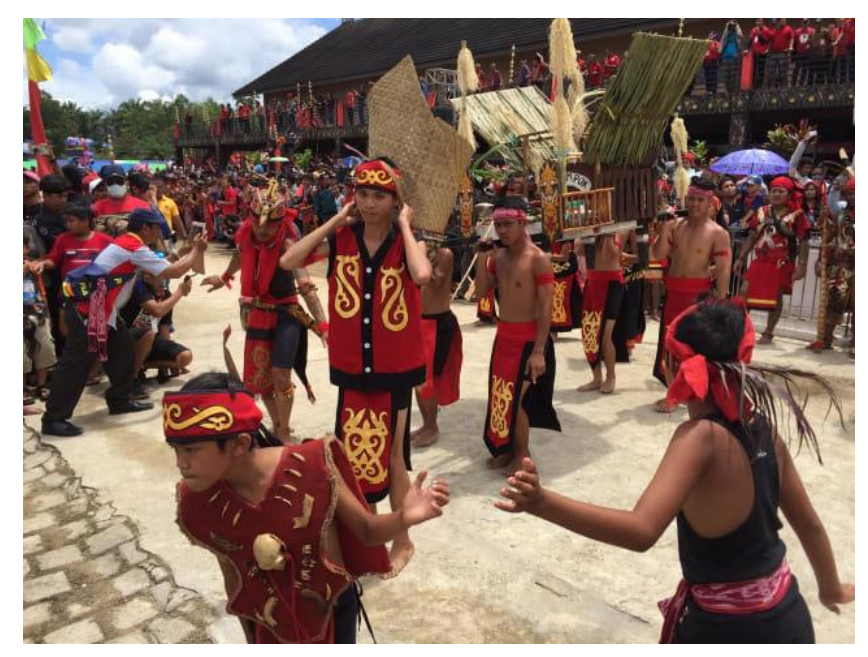

Figure 2. Naik Dango post-harvest ritual's after Nyangahatn

(Source, p. Kumparan, 2019) 
The reading of Matik (intent prayer) by Panyangahatn (ritual leader) in front of the prepared offerings. Matik is intended to inform Jubata and Awa Pama (ancestral spirits) regarding family needs. Matik is carried out at night before the planting activities are carried out the next day. After reading the Matik prayer, Panyangahatn will apply rice mixed with tengkawang oil or coconut oil to each person's forehead in attendance. This oil is believed to treat and protect the Kanayatn Dayak people from all diseases. At this stage, it is then continued with the Ngalantekatn prayer (salvation prayer), which aims to make the family and all those involved in the cooking work safe from all disturbances so that they can grow crops well and enjoy the harvest.

The next stage is the reading of the Nyangahatn Mibis prayer (prayer for all to reach the goal). This prayer aims that everything that has been asked of Jubata be granted. After the Mibis prayer, the chicken is slaughtered, and its blood is drawn as a symbol of sacrifice. The chicken is cleaned by removing only the intestines. Then the chicken is grilled or boiled to be eaten together. After reading the prayer, the residents will start cutting trees and grass in their paddy-rice fields. This activity is carried out by the family itself or in a balale' (cooperation). After the paddy-rice fields are considered ready to be planted, residents will start planting and hope that the crops will be good and produce a satisfactory harvest. The Nyangahatn ritual will be held again by residents at harvest time as a form of gratitude. Usually, this ritual is carried out festively and is known as Makatn Nasi'Barahu (eating freshly harvested rice) (Ibid., pp. 37-42).

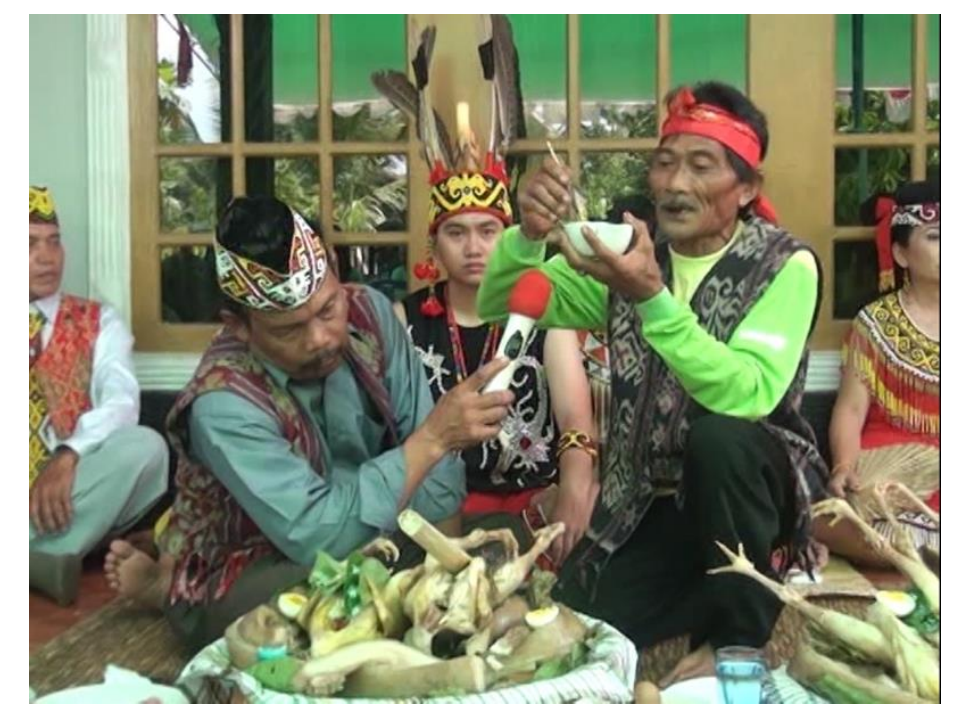

Figure 3. Nyangahatn Ritual's of Dayak Kanayatn Tribe

(Source: Directorate of Heritage and Cultural Diplomacy, 2018)

The Nyangahatn ritual is a pearl of local wisdom that is closely related to disaster mitigation and adaptation. First, in the process of carrying out the ritual when planting and harvesting time is certainly associated with the beginning of the rainy season to signify that the planting season will enter, and the arrival of the dry season to signify the harvest, secondly, using a fallow time (masa 
bera) after slash-and-burn will certainly increase fertility land to be used for cultivation. Forests or land cleared for cultivation are very calculated to avoid degradation and loss of water sources. The Kanayatn Dayak indigenous community is very aware of natural signs. In the process of clearing forests for agriculture, it is very important to know how vast the area of land is to be planted so that they do not disturb the forest ecosystem. Meanwhile, the balale' tradition (gotong royong or mutual cooperation) is a form of solidarity and harmony among community members. The planting and harvesting process can be completed on time.

\section{Conclusion}

The Kanayant Dayak indigenous community is one of the Dayak tribes in West Kalimantan. The majority are peasants and cultivators, both settled and shifting, who still maintain their traditions from generation to generation. This is evidenced by the Nyangahatn ritual, both before planting and post-harvesting. Not only that, the Nyangahatn ritual for the Kanayatn Dayak cultivating community has an important meaning in their life cycle, such as birth, marriage, and death, as well as medication. The Nyangahatn ritual is also local wisdom that is an effort in mitigating and adapting to disasters, especially regarding the planting and harvesting seasons. Forests or land cleared for cultivation are very calculated to avoid degradation and loss of water sources. The Kanayatn Dayak indigenous community is very aware of natural signs. In the process of land clearing for cultivation, it is very important to know how vast area of land to be planted so that they do not disturb the forest ecosystem. Meanwhile, balale' tradition (gotong royong) is a form of solidarity and harmony between community members.

\section{ACKNOWLEDGEMENT}

We gratefully thank the Ministry of Higher Education of Malaysia for the financial support under FRGS grants 1/2019, project 5540336. The researcher wishes to express the greatest appreciation and gratitude to Universiti Putra Malaysia.

\section{REFERENCES}

[1] Bell, Catharine. (2009). Ritual Theory, Ritual Practice. Oxford: Oxford University Press (second edition).

[2] Berianto, Alexius. (2013). "Makna Ritual Adat Nyangahatn dalam Upaya Pelestarian Adat dan Budaya Suku Dayak Kanayatn di Kabupaten Landak" Thesis, Christian University of Satya Wacana, Salatiga.

[3] Departemen Kebudayaan dan Pariwisata. (2009). Arsitektur Rumah Tradisional Rumah Dayak Bidayuh Kalimantan Barat. Jakarta: Direktorat Jenderal Nilai Budaya, Seni dan Film. 
[4] Direktorat Warisan dan Diplomasi Budaya (2018). Katalog Warisan Budaya Takbenda Indonesia I. Jakarta: Kementerian Pendidikan dan Kebudayaan Republik Indonesia.

[5] Juhadi, Abdul Muis dan Sriyanto. (2018). Kearifan Lokal dalam Mitigasi Bencana. Semarang: Fastindo.

[6] Keesing, Roger. M. (1974). “Theories of Culture," Annual Review of Anthropology 3: 37-97.

[7] Koentjaraningrat. (2002). Pengantar Ilmu Antropologi. Jakarta: Rineka Cipta (edisi kedelapan).

[8] Kumparan, (2019). "Naik Dango, Ritual Hasil Panen oleh Suku Dayak Kanayatn," https://kumparan.com/hipontianak/naik-dango-ritual-hasil-panen-oleh-suku-dayak- kanayatnIqyRXM4iG7kffull. Accesed at June $23^{\text {th }} 2021$.

[9] Magiman, Mohammad Maulana, Hazizy Hanis, Mangai Tugau, Ahmad Nasir Mohd Yusoff. (2020). "The Symbols Rituals of Salako Community in Sarawak" Opción Journal 36 (26): 3005-3023.

[10] Marzali, Amri. (2003). Strategi Peisan Cikalong dalam Menghadapi Kemiskinan. Jakarta: Yayasan Obor Indonesia.

[11] Odum, Eugene. P. (1983). Basic Ecology. Philadelphia: Saunders College Publishing.

[12] Purba, Jonny. (2005). Pengelolaan Lingkungan Sosial. Jakarta: Yayasan Obor Indonesia.

[13] Purwana, Bambang H.Suta. (2019). "Fungsi Mite Asal Mula Padi Dalam Tradisi Agraris Masyarakat Dayak Bidayuh di Kalimantan Barat," Jantra Journal 14 (1): 65-74.

[14] Purwanto, Semiarto Aji. (2009) “Kata Pengantar: Makna dan Fungsi Arsitektur Tradisional Dayak Bidayuh" Arsitektur Tradisional Rumah Dayak Bidayuh Kalimantan Barat: v-xiv. Jakarta: Departemen Kebudayaan dan Pariwisata.

[15] Rappaport, Roy A. (1999). Ritual and Religion in the Making of Humanity. Cambridge: Cambridge University Press.

[16] Rensch, Calvin R. et. al.(2012). The Bidayuh Language: Yesterday, Today, and Tommorow. Texas: SIL International Publishing.

[17] Soemarwoto, Otto. (2004). Ekologi, Lingkungan Hidup dan Pembangunan. Jakarta: Djambatan (tenth edition).

[18] Wahyuningtyas, A. dan R.A. Pratomo. (2015). "Identifikasi Multi-Bencana di Kabupaten Landak Kalimantan Barat" Journal Geomatics and Planning 2 (1): 10-21. 